\title{
JUURNAL.RU
}

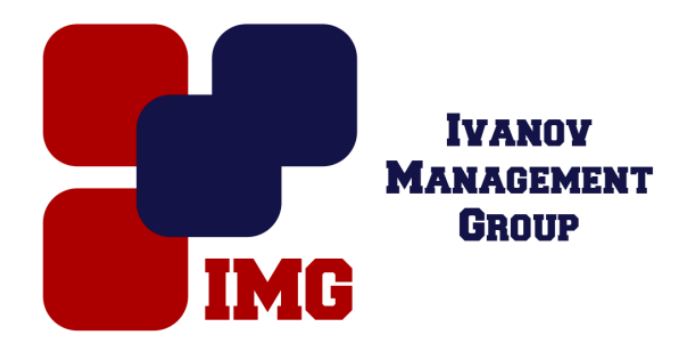

Лайпанова 3.М., Шидакова М.А. СевКавГГТА Черкесск, Россия

doi: 10.18411/1j-30-06-2017-23

idsp 000001:1j-30-06-2017-23

\section{Учет удержаний по исполнительным листам}

Удержание из заработной платы работника - это неперечисление (невыдача) части заработной платы, причитающейся работнику, в обеспечение требований к этому работнику либо со стороны работодателя, либо со стороны третьих лиц, осуществляемое в случаях, размерах и порядке, установленных ТК РФ и иными федеральными законами.

Удержания из заработной платы работника производятся только в случаях, предусмотренных Трудовым кодексом РФ и иными федеральными законами. Только в ТК РФ и иных федеральных законах (ст. 137 ТК РФ) установлены случаи удержаний из заработной платы. Поэтому работодатель не может произвольно вычитать суммы из заработной платы работника, а обязан руководствоваться трудовым законодательством.

Каждое учреждение начисляет заработную плату своим работникам. Одновременно производятся удержания, уменьшающие размер заработной платы. Поэтому работник заинтересован в том, чтобы размер удержаний был как можно меньше или причины для удержания отсутствовали вовсе. Трудовое законодательство устанавливает достаточно жесткие правила, которые определяют случаи, размеры и порядок удержаний из заработной платы работников. Их следует знать как работникам, так и ответственным лицам, занимающимся выплатой заработной платы работникам.

Исполнительный лист является исполнительным документом, направленным на принудительное исполнение решения суда. Взыскание сумм из заработной платы работника осуществляет бухгалтерия на основании направленного исполнительного листа государственным исполнителем. 
Государственный исполнитель, кроме исполнительного листа, направляет предписание, в котором указывается лицо (юридическое или физическое), в пользу которого осуществляется взыскание. Копию этого распоряжения получает также и должник. При получении исполнительного листа и распоряжения предприятие должно вернуть государственному исполнителю Уведомление о его получении, что является частью распоряжения. Указанное уведомление подписывается главным бухгалтером предприятия. Подпись заверяется печатью.

Основанием для удержания алиментов являются исполнительные листы, а при их утрате - дубликаты этих листов, а также письменные заявления граждан о добровольной уплате алиментов.

Поступившие в бухгалтерию организации исполнительные листы регистрируют в специальном журнале и хранят как бланки строгой отчетности. О поступлении исполнительных документов бухгалтерия сообщает судебному исполнителю и взыскателю.

В поступившем в учреждение исполнительном документе должны содержаться:

- наименование суда или другого органа, выдавшего исполнительный документ;

- дело или материалы, по которым выдан исполнительный документ, и их номера;

- дата принятия судебного акта или акта другого органа, подлежащего исполнению;

- наименования взыскателя - организации и должника - организации, их адреса; фамилии, имена, отчества взыскателя - гражданина и должника - гражданина, их место жительства, дата и место рождения должника - гражданина и место его работы;

- резолютивная часть судебного акта или акта другого органа;

- дата вступления в силу судебного акта или акта другого органа;

- дата выдачи исполнительного документа и срок предъявления его к исполнению.

Исполнительный документ должен быть подписан судьей (должностным лицом другого уполномоченного органа, выписавшим исполнительный документ) и заверен гербовой печатью суда (печатью органа или лица, его выдавшего). О поступлении исполнительного документа в учреждение судебный исполнитель и взыскатель должны быть уведомлены. 
Обычно в исполнительном листе указываются почтовые реквизиты получателя алиментов, поэтому широко распространено их получение в почтовом отделении на основании почтового перевода. Однако родитель, в пользу которого удерживаются алименты на содержание ребенка, может изъявить желание на перечисление их на счет в банке либо получить их в кассе учреждения, в которой работает ответчик. Для этого взыскатель представляет в бухгалтерию учреждения, которая осуществляет удержание алиментов, заявление о способе их получения по своему усмотрению. В течение трех дней со дня выдачи заработной платы алименты должны быть выплачены на основании расходного ордера, либо переведены по почте акцептованным платежным поручением, либо перечислены в отделение Сбербанка на лицевой счет получателя.

Удержанные суммы алиментов бухгалтерия обязана в течение трех дней со дня выплаты заработной платы выдать взыскателю лично из кассы, перевести по почте акцептованным платежным поручением (с отнесением расходов по переводу на взыскателя) или перечислить на счета взыскателей по вкладам в отделение Сберегательного банка на основании письменного заявления заявителя. Если адрес заявителя неизвестен, удержанные суммы перечисляют на депозитный счет народного суда по местонахождению организации.

Расходы учреждения по переводу алиментов удерживаются из заработной платы должника. Если адрес получателя алиментов неизвестен, то учреждение уведомляет об этом судебного исполнителя. В случае увольнения работника, уплачивающего алименты, администрация учреждения, производившая удержание алиментов на основании решения суда или нотариально удостоверенного соглашения, обязана в трехдневный срок сообщить судебному исполнителю по месту исполнения решения о взыскании алиментов и лицу, их получающему, об увольнении лица, обязанного уплачивать алименты, а также о новом месте его работы или жительства, если оно ей известно.

В контрольный лист к исполнительному листу заносятся данные обо всех удержаниях алиментов, а также о суммах оставшейся задолженности, после этого документ заверяется печатью учреждения. В течение трех дней он должен быть отправлен заказным письмом в службу судебных приставов или в суд по месту жительства должника. Удержание алиментов производится в следующих размерах

- на содержание одного ребенка - 1/4 дохода работника или 25\%;

- на содержание двоих детей - 1/3 дохода работника или 33\%;

- на содержание троих и более детей - 1/2 дохода работника или 50\%

Алименты могут удерживаться на основании поданного заявления 
работника. Удержания по исполнительным документам на несовершеннолетних детей не должны превышать $70 \%$ суммы заработной платы после удержания налогов и сборов, а для других алиментных взысканий - 50\%.

Задолженность по исполнительному листу может быть связана с:

- неуплатой алиментов на ребенка или жену;

- возмещением причиненного морального или материального ущерба;

- штрафами за административные правонарушения;

- неуплатой налогов, страховых взносов, пеней и других сборов.

Как правило, алименты уплачивают родители, находящиеся в разводе. Если один из них отказывается содержать своего несовершеннолетнего ребенка, то второй родитель вправе потребовать выплаты денежных сумм через суд.

Алименты из суммы начисленного работнику вознаграждения удерживаются ежемесячно на основании исполнительного листа или соглашения. Родители могут без участия суда решить вопрос об уплате алиментов на содержание детей, заключив письменное соглашение, заверенное нотариусом, которое имеет силу исполнительного листа. Исполнительные листы и соглашения о выплате алиментов при поступлении в организацию передаются бухгалтеру, назначенному приказом руководителя ответственным за их хранение, под расписку и в обязательном порядке регистрируются в специальном журнале, который ведется в произвольной форме.

Алименты на содержание несовершеннолетних детей устанавливаются в твердой денежной сумме или в размере: на 1 ребенка - 1/4, на 2 детей - 1/3, на 3 детей и более - 50\% заработка (дохода), но не менее суммы, установленной законодательством.

Размер этих долей может быть уменьшен или увеличен судом с учетом материального или семейного положения сторон или иных заслуживающих внимания обстоятельств. При этом сумма алиментов не может превышать $70 \%$ заработка работника, уменьшенного на сумму налога на доходы физических лиц.

Суд может установить размер алиментов в твердой денежной сумме, соответствующей определенному числу минимальных размеров оплаты труда. В этом случае организация должна индексировать алименты пропорционально увеличению сирот. 